Project Accomplishment Summary For

Project Number 93-MULT-021-D1-4B

\title{
WELDING AND WELDABILITY OF DIRECTIONALLY SOLIDIFIED SINGLE CRYSTAL NICKEL-BASE SUPER-ALLOYS
}

\author{
John M. Vitek \\ Lockheed Martin Energy Systems, Inc. \\ Thomas J. Fitzgerald \\ Westinghouse Electric Corporation
}

September, 1996

\author{
Prepared by the \\ Oak Ridge Y-12 Plant \\ managed by \\ LOCKHEED MARTIN ENERGY SYSTEMS, INC. \\ for the \\ U.S. DEPARTMENT OF ENERGY \\ under contract DE-AC05-84OR21400
}




\section{DISCLAIMER}

This report was prepared as an account of work sponsored by an agency of the United States Government. Neither the United States Government nor any agency thereof, nor any of their employees, makes any warranty, express or implied, or assumes any legal liability or responsibility for the accuracy, completeness, or usefulness of any information, apparatus, product, or process disclosed, or represents that its use would not infringe privately owned rights. Reference herein to any specific commercial product, process, or service by trade name, trademark, manufacturer, or otherwise, does not necessarily constitute or imply its endorsement, recommendation, or favoring by the United States Government or any agency thereof. The views and opinions of authors expressed herein do not necessarily state or reflect those of the United States Government or any agency thereof. 


\section{PROJECT ACCOMPLISHMENT SUMMARY}

Title: $\quad$ Welding and Weldability of Directionally Solidified Single Crystal

CRADA Number: Y1293-0178

DOE TTI Number: 93-MULT-021-D1-4B

Partner:

Westinghouse Electric Corporation

\section{BACKGROUND}

Nickel-base super-alloys are attractive for turbine-engine applications because of their hightemperature strength and corrosion resistance. Particularly important for high temperature applications is the high-temperature creep resistance. In order to improve engine efficiency, there is a desire to increase the operating temperature range of turbine engines to higher temperatures. This has led to an evolution of nickel-base super-alloys, from polycrystalline alloys to directionally-solidified alloys to single-crystal alloys. By aligning the grain structure with the stress axis in directionally-solidified materials, substantial improvements in high-temperature creep resistance were realized. Still further gains have been made when single-crystal alloys, without the presence of grain boundaries, were substituted for directionally-solidified materials. Currently, engine parts are made up of all three types of materials.

Welding is an attractive method for fabricating turbine engine components. However, welding is not used extensively because of the vulnerability of nickel-base super-alloys to hot cracking. In addition, welding may critically alter the grain structure in these alloys, which may lead to poor performance. Nonetheless, welding is attractive because of its potential for large economic benefits. Furthermore, welding is potentially useful in component repair operations. As a turbine engine manufacturer, Westinghouse Electric Corporation was interested in evaluating the potential for incorporating welding in the overall fabrication of turbine engine components. Lockheed Martin Energy Systems had extensive experience in evaluating the weldability of materials and, more recently, had experience with welding of single crystals and evaluating the impact of welding on the single crystal grain structure.

\section{DESCRIPTION}

The objective of this CRADA project was to investigate the weldability of polycrystalline, directionally-solidified, and single-crystal, nickel-base super-alloys. These materials are used extensively in turbine engine components. The ability to weld these materials is highly desirable in that it would greatly facilitate component fabrication. Welding of these materials would also have the potential benefit of allowing for the repair of cracked or worn components. Specifically, the program had four objectives:

1. to evaluate the weldability of nickel-base super-alloys;

2. to characterize the solidification microstructure of the welds;

3. to evaluate the phase stability of the weldments during exposure to service conditions; and

4. to determine the mechanical properties of the welds. 
Westinghouse Electric Corporation was to supply material for the program, in both as-case and heat-treated form. This was to include commercially available as well as experimental alloys developed at Westinghouse. ORNL was to perform weldability tests on the materials using a variety of welding procedures.

\section{BENEFITS TO DOE}

Nickel-base super-alloys are used extensively in turbine engines for both aircraft and land-based systems. The knowledge gained through this CRADA is valuable as far as learning what welding processes and methods may be available for use with these alloys, both for component fabrication as well as for component repair. The present study provides guidance for determining process. In addition, valuable experience with this class of materials has been gained. This experience with the welding of nickel-base super-alloys can be applied to systems other than just turbine systems. For example, nickel-base super-alloys are used extensively in the production of nuclear weapons and the expertise gained through this CRADA can be directly applied to the solution of problems that arise in these, and other, manufacturing enterprises.

\section{ECONOMIC IMPACT}

In general, the results from this study show that the nickel-base super-alloys are extremely vulnerable to cracking. However, conditions under which acceptable welds can be produced have been identified for some alloy combinations. This information can be incorporated into commercial practice. The project provided valuable insight into the potential for using welding during the fabrication of turbine engine components as well as during the repair of worn components. For service conditions where directionally-oriented grains are acceptable, welding may provide a simple and cost-effective alternative to current component fabrication. In addition, the studies have shown that weld repair of these materials is also feasible. Serious problems were found but guidelines as to what conditions could be conducive to implementing welding in the manufacturing cycle were identified. Westinghouse Electric Corporation is following up the research in this CRADA with an industrial partner to try to utilize welding during the fabrication of specific engine components.

\section{PROJECT STATUS}

The project has been completed.

\section{DOE FACILITY POINT OF CONTACT FOR PROJECT INFORMATION}

Lockheed Martin Energy Systems:

John M. Vitek

Lockheed Martin Energy Systems

Oak Ridge, Tennessee 37831-6376

Phone: 423 574-5061

Fax: 423 574-0641 


\section{COMPANY SIZE AND POINT OF CONTACT}

This program was conducted with the Westinghouse Power General Business Unit (PGBU), a subsidiary of Westinghouse Electric Corporation. Westinghouse PGBU had sales of $\$ 2$ billion in 1996 and had 5600 employees. The contact person at Westinghouse PGBU who was involved in this program is:

Thomas J. Fitzgerald

Westinghouse PGBU

Orlando, Florida

Phone: 407 281-5541

Fax: 407 281-2334

\section{TECHNOLOGY COMMERCIALIZATION}

At the end of this CRADA, no commercialization of the technology had been planned. Westinghouse PGBU has plans to further research the technology to determine if commercialization possibilities exist. 


\section{Distribution List}

John Vitek, MS 6376, 5500

Peter Angelini, MS 6065, 4515

Everett Bloom, MS 6117, 4500-S

Ron Bradley, MS 6161, 4500-S

Douglas Craig, MS 6132, 4500-S

Ray Ford, MS 8084, 9203 (RC)

Joyce Shepherd, MS 6416, 5002

Andy Stevens/DOE OR, MS 8009, 9704-2

Diane Bird, DOE DP-17

Brian Hooper, DOE DP-17

Bill Wilburn, MS 8015, 9704-2

Lab Records, MS 6285, 4500-N

Y-12 Central Files, MS 8169, 9711-5 (3 copies)

Thomas Fitzgerald, Westinghouse Electric Corporation, 4400 Alafaya Trail - MC 303, Orlando, Florida 32826-2399 (5 copies) 